\title{
The Localized Productive System: A Literature Review
}

Youssef Moflih

Professor and Researcher, Department of Economic Sciences \& Management, Laboratory of Research on the New Economy \& Development, University of Hassan II, Casablanca

\begin{abstract}
The localized productive system developed (LPS) by Courlet (1994) helps circumscribe the organization that binds the enterprises together in a territory and highlight the nature of the benefits (positive externalities, reduced transaction costs, better coordination between the actors of a territory) yielded by proximity. Indeed, the LPS is far from being a concept in the true sense of the word because it is interpreted in several ways. The LPS can be attached first to a broader interpretation of the economic phenomena: either it is the new techno-organizational paradigm of reference resulting from the swing of the global mode of production or it is a component or even a transition state of the new industrial organizations that are being set up. The LPS can also be attached to a more specific interpretation referring to the history of economic development according to which any local reality would be, at some point, more or less an LPS. It is but a unit of analysis, which, as the organization, sees its theoretical foundations vary according to approaches and authors. This means that the literature only analyzes the forms of organization in local systems, without explaining their foundations nor their evolution.
\end{abstract}

Keywords - externalities, Innovation, LPS, proximity, territory.

\section{INTRODUCTION}

The localized productive system (LPS) is at the center of debates over the relationships between industry and territory. It appears as a synthesis that helps to apprehend the connections between economic dynamics and territory (Courlet and Pecqueur, 1996). For Courlet (1999) this concept "comes from the combination of the different contributions of recent literature on the subject: the proposals of $F$. Wilkinson who introduces the notion of production system, those of G. Garofoli (1983) with the idea of a local production system to highlight the deep symbiosis between the economic and socio-cultural phenomena, and finally, those of some French authors with the localized production system term to introduce the role of local regulations (Raveyre, Saglio, 1984; Courlet, Pecqueur 1991 ; Ganne, 1992; Courlet, Soulage, 1994)." The notion of a localized production system is presented www.ijaems.com as a set of interdependent activities, technically and economically organized, and territorially agglomerated. This concept also means "a collective way of living, thinking and producing, peculiar to a company, a space, a milieu. It expresses arrangements, specific practices and ways of social and economic organization. It defines a specific structuring of the game of economic and social relationships between actors in a delimited geographical and socio-cultural space"(Dimou 1994). The LPS is thus three-dimensional as it integrates the spatial, organizational and institutional dimensions.

\section{THE LPS: DEFINITION ATTEMPT}

The LPS allows to give account of the role of SMEs and their cooperation in a given territorial framework without neglecting the effects of proximity and the local sociocultural context. The localized production systems present the SME mainly in a corporate system. The proximity of agents belonging to the same establishment space, as opposed to the distant and external, is a fundamental characteristic of the localized production systems. Paraphrasing Pecqueur (2000), one might call this phenomenon "the dialogue of enterprises and territories." Indeed, the LPS differs from the industrial district in many aspects such as the fact that the enterprises are not necessarily concentrated in a single branch or specialized in the production of components of a single product. In addition, in the LPS, it may be a matter of territorialized relations between SMEs but also between SMEs and large enterprises and even between large enterprises. In other words, the LPSs are not confined by the traditional subcontracting relations between enterprises (Courlet and Soulage, 1994, 18). Moreover, the LPSs are also characterized by their great flexibility and their ability to meet variable and differentiated demands in time and space.

The LPSs can in fact be rooted in a long artisanal tradition that is gradually switching to an industrialization process, be part of a dynamic linked to the "territorial decentralization of production" (Garofoli, 1992) or to the "vertical disintegration "(Leborgne and Lipietz, 1992) and be present in low-density environments such as the metropolitan areas.

Page | 259 
Proximity, networks, competition and cooperation are the basic ingredients of an industrial organization characterized by a spatial concentration of production. By adding the specialization of enterprises in a trade and/or a product to these components, the main characteristics of localized production systems, as defined by DATAR (a Former French Inter-Ministerial Delegation to Spatial Planning and Regional Attractiveness), are then met.

Thus, DATAR relies broadly on Courlet's (1994) definition of the Localized Production System to define one of its aid programs to local economic development within a comprehensive framework of spatial planning: "The Localized Production System can be defined as a configuration of enterprises grouped together in a proximity space, revolving around a trade or even several industrial trades. The enterprises entertain relationships between themselves and with the socio-cultural milieu of integration. They are not fully market relationships, they are also informal and produce positive externalities for all the enterprises. The dominant industrial trade does not exclude the possibility of several industrial branches."

More explicitly, we can say that an LPS is a cluster of production units located in the same territory and entertaining diverse relationships, more or less intense. This term is tricky because it covers some realities and very different underlying theories. (Courlet (2001) provides a detailed analysis of this notion and empirical and theoretical works on its usage).

This definition attempt of the LPSs would also emphasize the relational dimension of the various units of productions in a proximity space. The grouping around a trade or product seems to be irrelevant to be the source of its success. The key to a successful LPS is largely contingent upon its ability to provide "specific territorial resources."

The LPS is only the fruit of coincidence and not a development model. For Garofoli (1996) "the theoretical problem, in connection with the economic policy and development strategy, is the possibility of the territorial diffusion of industrialization and the transfer of the model to other regions." It cannot just spring up anywhere or any time because it is based on a fundamental spatial dimension that conveys specific socio-cultural characteristics.

The LPS consists also of a cluster of SMEs connected or not to one or many large enterprises located in the same proximity space (local or sub-regional) and revolving around a trade, or even several industrial trades. There is a dense network of interdependencies between the various enterprises affiliated with the LPS. These relationships "range from the pursuit of a specialized production, which one enterprise cannot achieve, to the development of outstanding economies of scale" (Courlet and Soulage, 1994, page 18). Therefore, there are particular market relationships between the enterprises in the case of specialized production, and cooperation relationships in the case of the pursuit of external economies of scale. For goods and services not to mention employment, the LPS is based on a system of regulation that appeals not only to the rules of the market but also to a social code, to social forms: rules, values, etc.

The LPS is in line with the pursuit of the territorial dynamics and the industrial localization, which are subjects of studies shared at the same time by economists, sociologists and geographers. For economists who study the LPS the market is central to their construction, they do not neglect the specificity of the firm and underline the competition-cooperation blend to which it is committed; the specificity of these production forms comes then from this arrangement of apparently opposing forces. Their specificity seems to be in the combination of analytical tools borrowed from both economy and sociology, which may reveal a sense of theoretical fragility.

The LPS is based broadly on the tight interdependent relationships between the local actors in the form of external economies and advantages in their production activity. External economies of agglomeration show up too once tight relationships are affirmed in a limited spatial context (Pecqueur, 1992).

In fact, Pecqueur (1992) insists on the existence of three characteristics that are the density, the form and the small (the space limitation), to speak of the existence of an LPS whose industrial district is but a particular configuration.

\section{CHARACTERISTICS OF THE LPSs:}

\section{1- ORIGIN OF THE LPSs:}

The notion of the LPS is inspired by the recent analyses of the industrial economy and the regional economy on innovation (Courlet, 2001b). Therefore, two types of analyses can be undertaken. The first gives more importance to the milieu rather than the enterprises: the supporters of this trend insist that the milieu predates the birth of enterprises and that it begets innovation. We are talking about a "theory of milieus development" rather than a "theory of enterprises localization" (Aydalot 1986). The second trend is rather focused on industrial organization as such (Perrin, 1992), and particularly on response strategies to the crisis of Fordism, and thus on the search for flexibility and integration. However, both approaches insist on the identity of the milieu and the conventions that stipulate more or less explicit norms.

For the researchers (Garofoli, 1992; Courlet 2001b, Leborgne \& Lipietz 1992, Courlet \& Soulage 1994, and others), the LPSs may result from two processes: On the one hand, we find LPSs coming from a long artisanal-like tradition which traversed the Fordist era and was the cornerstone of a gradual process of diffuse industrialization. In these systems that one might call

Page $\mid \mathbf{2 6 0}$ 
"old", the workforce high versatility, and particularly its ability to undertake, plays a decisive role. On the other hand, we also find "recent" LPSs whose formation is the outcome of a search for solutions to the crisis of the Fordist model. This formation can illustrate the regulation theses that explain the transition from one type of organization to another (Courlet, 2001b). The LPS is therefore the result of a "territorial decentralization of production" (Garofoli, 1992, page77) or what others call "vertical disintegration" (Leborgne and Lipietz, 1992). It also responds to the search for a highly involved workforce in working in a micro-social context lightly affected by Fordism. In these recently built up systems, qualification and the milieu's innovative capacity are intrinsic factors.

Finally, this development mode may appear not only in rural areas but "in areas featuring a dense urban mesh" (Courlet and Soulage, 1994, page 19). In any case, they are productive systems deeply embedded in the community so that reciprocity and cooperation can complement the exchanges regulated by the market. This obviously involves local institutions concerned with the local development.

\section{2- LPSS AND ECONOMIES OF GLOMERATION:}

To characterize the LPSs, Courlet (2001a, 2001b) introduces the notion of economies of agglomeration. These are well defined by Arthur: "(...) economies of agglomeration mean that the net profits yielded by an enterprise from a localization in the neighborhood of other firms increase with the number of firms that are in the same localization. The sources of the economies of agglomeration are diverse: at the same time as there is a growing number of established firms in a localization area, the latter gains ground in infrastructure. Its labor market grows. Financial services and specialized offices emerge. Spare parts and obsolete stock become available locally, thereby reducing storage costs. Social networks begin to exist where information, expertise and contracts can be easily exchanged"(Arthur, 1995, page 299).

These economies are therefore the result of the tight relationships between the local enterprises which "amplify labor division thus making room for more specialization" (Courlet 2001b, page 78). The result is "a set of relationship networks between actors" that form a "local industrial fabric" (Pecqueur, 1987).

Therefore there is a vertical quasi-integration (Leborgne and Lipietz, 1992) whose characteristics are "stable relationships between suppliers and customers; a substantial customer share in the supplier's turnover; subcontracting ranging from design to marketing; nonmarket forms of inter-firm relationships going from subordination to partnership"(Leborgne and Lipietz, 1992). However, "the vertical quasi-integration implies also the extension of non- market relationships between firms: strategic alliances, technology transfer, joint research programs, joint venture". Thus, "the leading firm obtains both the benefits of the vertical integration (transactions at low cost, just-in-time management, flexibility of the overall policy) and those of the vertical disintegration (innovation opportunities among subcontractors, imposition of quality standards, risksharing of development-research and fixed assets)"(Billette and alii, 1991).

As concluded, a localized production system is made of more or less heterogeneous activities, more or less interdependent, with more or less coherence and cooperation, and having various types of external connections. However, at this stage, a reflection on the phenomena of LPSs organization allows further study of its various mechanisms.

\section{3- LPSs AND ORGANIZATION:}

Our goal is to know what organization mechanisms can influence the competitiveness of the production system. Yet, the successes and failures of the policy of creating counterweight metropolises in France or in developing countries show that the process of industrializing industry in growth centers as a consequence of the direct and indirect market spread effects is by no means automatic, even if the injected capital is important. But this finding is too general to be used straightaway. It would be appropriate to question the background of this greater productive efficiency.

Traditionally, an increase in a business profitability is a result of three factors:

- Lower production costs thanks to a more effective technology (in the broad sense, including labor) and reducing the inputs cost (including transaction costs).

- Cheaper access to a larger market thanks to lower costs of transport (or more generally the distance) and distribution (including transaction costs).

- Finally, the stimulation of demand by providing the quality characteristics desired by consumers (principle of differentiation)

These three "sources of profitability" constitute the first read key of organization effects. However, with the consideration of space in the analysis, the debate on the need to take into account non-market mechanisms allows to draw other intrinsic factors. First, the external effects, along the same line of Marshall's work, which are found in the evolutionist trend, but can also be integrated into a microeconomic formalism. In these works, the gain function of economic agents depends on their interaction with their neighbors. Also, with the importance of transaction costs in some situations, which concerns mainly the neo-institutionalist approach, the organization 
is studied not only between the actors but also "inside the agents" that are the enterprises whose borders can be indistinct.

The distinction between external economies and transaction costs is sometimes uncertain. Besides, some authors as Coase think that both mechanisms are intrinsically linked. Thus, the preferential access to local natural resources could also be seen as a positive externality. The co-operations are not literally external economies, but are close. On the other hand, some actions are double-sided. For example, from a production perspective, competence self-reinforcement is a positive externality for local enterprises. From a recruitment perspective, it offers savings in transaction costs for both workers and enterprises. Thus, we must remember that this classification does not attempt to transcend the various researches on the economic organization phenomena, but to deepen the analysis of the diversity of potential relationships between organization and economic efficiency.

Some works attempt a more detailed description of the basic mechanisms at play in the localized production systems. Perrat (1997) proposes a detailed reading key of the different types of externalities, intersecting a "functional" approach with a "substantial" approach. We will stick to this simple classification, which will help us to examine the possible developments in terms of formalizing organization effects. In order to use it in the rest of the document, we will present the identified mechanisms in the following way that brings together the organization effects per element of the production process concerned:

- Factors access and prices: preferential access to local natural resources, preferential access to credit, specialized workforce, a captive, accepting lower wages.

- Firms internal efficiency: quality of workforce, competence self-reinforcement.
- Relationships between firms: vertical complementarities and ad hoc cooperation, technical information circulation, market information circulation, loyalty to local suppliers, goods used in common.

- Relations with the markets: preferential rates, effective mobilization of distributors, loyalty to local products, barriers to entry.

- Nature of demand: atmosphere conducive to innovation, reliance on product quality, horizontal complementarities, lower advertising costs, responsiveness to exogenous shocks.

\section{4- LPSs AND INNOVATION:}

Several studies defend the idea that the LPS is a specific organization that creates technologies whose "own innovation capacities would emerge over the course of their history and explain the dynamics thereof" (Ragni 1997). Also, the LPS is a milieu where the process of innovation could be permanent since the different stakeholders seek "to determine the external conditions necessary for the birth of the enterprise and adoption of innovation" (Benko and Lipietz 1995). Innovation is a product of the activity (Courlet 2001b), and usually in continuity with the experience acquired by the milieu (Courlet and Soulage, 1994), and in addition, the "geographically neighbor enterprises are more likely to exchange knowledge formally or informally (...) all this confirms the importance of geographical proximity between economic actors, and encourages the consideration of the weight of spatial networks of knowledge" (Courlet 2001a). Or even more, in the case of radical innovations, taking into account the relationships with milieu-oriented institutions (university research centers). Hence the importance of governance to translate "all non-market and State-controlled regulation forms." In other words, "governance is civil society minus the market" to which adds "the local political society, community leaders, municipalities" (Benko and Lipietz, 1992).

- A cluster of enterprises operating in one or more branches and located in the same territory (region or local area);

- Strong interdependence between enterprises, whether between SMEs, between SMEs and one or more large enterprises or even between large enterprises (vertical integration or quasi-integration);

- Ability of enterprises to meet a final variable and differentiated demand in time and space (flexible production units);

- Existence of a strong regional or local identity promoting cooperation and reciprocity between the enterprises and the various stakeholders;

- Presence of rules and conventions (usually unwritten) promoting industrial coordination (rules protecting local production, support to local enterprises, local purchasing, local reinvestment, priority of hiring local workforce etc.);

- Presence of local institutions, communal and public, likely to ensure local governance and therefore to ensure private interests and public property articulation, articulation of economic and social aspects;

- Existence of a local workforce pool (versatility);

- Atmosphere and institutional support promoting innovation and the emergence of new enterprises.

Fig. 1: Key points to remember on LPSs 


\section{CONCLUSION}

Though there is no real similarity between the two concepts and the phenomenon of the Third Italy remains unique, the LPS and the Industrial District are always used together. The Grenoble school, formed mainly by Courlet Claude and Pecqueur Bernard remains directly linked to the Italian school which digged out the old term of Marshall. However, the industrial district and the LPS concepts constitute each distinctive features of the "standard categories" of the industrial territories. Finally, Districts and LPSs remain:

- As part of a more general process of "refocusing" / return to the local.

- As the core of a new post-Fordist economy, localized and of small scale

- As mythologies, labels and self-fulfilling prophecies.

\section{REFERENCES}

[1] Arthur B (1995): «Les localisations en grappe dans la 'silicon valley': à quel moment les rendements croissants conduisent-ils à une situation de monopole? / The clustered localizations in the 'silicon valley': when do increasing yields lead to monopoly?» in: Rallet A. \& Torre A. (1995).

[2] Azaïs C (1997) «Dynamique territoriale, localisation et Systèmes Productifs Locaux : quelques repères théoriques/Territorial dynamics, localization and Local Production Systems: some theoretical benchmarks » in Palloix C et Rizopoulos $\mathrm{Y}$ « Firmes et économie industrielle/Firms and industrial economy», L'Harmattan editions.

[3] Aydalot P (1986) «Milieux innovateurs en Europe/Innovative milieus in Europe» Paris, GREMI.

[4] Bailly A, Ferras R, Pumain D «Encyclopédie de géographie/Geography Encyclopedia » Economica, Paris, 1992.

[5] Bagnasco, A., Sabel (1994) «PME et développement économique en Europe/SMEs and economic development in Europe» Paris, La Découverte.

[6] Becattini G (1989) «les districts industriels en Italie/The industrial districts in Italy» in Maruani M et Reynaud E \& Romani C (1989) « La flexibilité en Italie /Flexibility in Italy », Tenmire, Syros, Paris.

[7] Bellet M (1992) «Technologie et territoire: l'organisation comme objet de recherche/ Technology and territory: the organization as a research subject», in «Revue française d'économie», vol VII, n 1 , France.

[8] Bellet M, Colletis G, Lecoq B, Lung Y, Pecqueur B, Rallet A, Torre A (1992) «et Pourtant ça marche! Quelques réflexions sur l'analyse du concept de proximité/And yet it works! Some reflections on the analysis of the concept of proximity » in "Revue économie industrielle", $\mathrm{n}^{\circ} 61$, $3^{\text {rd }}$ quarter.

[9] Benko G, Lipietz A (1992), «Les régions qui gagnent, District et réseaux: les nouveaux paradigmes de la géographie économique/Regions that win, District and networks: the new paradigms of economic geography» PUF, Paris.

[10] Benko G, Lipietz A (1995) «De la régulation des espaces aux espaces de regulation/From Regulation of spaces to spaces of regulation » in Boyer $\mathbf{R}$ et Saillard $\mathbf{Y}$ «Théorie de la régulation, l'état des savoirs/Regulation theory, the state of knowledge» La Découverte Editions, Paris.

[11] Benko G, Lipietz A (2000), «La richesse des regions/The wealth of regions", PUF, Paris.

[12] Benko G (1998) «La science régionale/The regional science » coll. «que sais-je», Puf Editions, Paris.

[13] Benko G (1990) «La dynamique spatiale de l'économie contemporaine/ The spatial dynamics of the contemporary economy» l'Espace européen Editions, Paris

[14] Benko G, Dufnord M, Lipietz A (1996) «les districts industriels revisités/The industrial districts revisited » in Pecqueur B (1996).

[15] Billette A, Carrier M, Saglio J (1991) «Structuration sociale d'un système industriel de PME : le cas de la région de St-Georges-deBeauce/Social structure of an industrial system of SMEs: the case of the St-Georges-de-Beauce region» Quebec, University of Laval.

[16] Bradelli P, (1996)«Le modèle de production flexible/ The flexible production model» PUF, coll. Que sais-je?, Paris.

[17] Camagni R (2002), «Compétitivité territoriale, milieux locaux et apprentissage collectif: une contre-réflexion critique/Territorial competitiveness, local milieus and collective learning: a counterreflection critique», in «Revue d'économie régionale et urbaine», $\mathrm{n}^{\circ} 4$.

[18] Catin M (1994) «Externalités/Externalities » in Auray J-P, Bailly A, Derycke P-H, Huriot J-M (1994) «Encyclopédie d'économie spatiale/Spatial economy encyclopedia » Paris, Economica.

[19] Courlet C (2001a), «Les systèmes productifs locaux: de la définition au modèle/Local production systems: from the definition to the model. » in «Réseaux d'entreprises et territoires, Regards sur les systèmes productifs locaux./Enterprise Networks and Territories, a look at local production systems », La DATAR, La documentation française.

[20] Courlet C (2001b) «Territoires et régions, les grands oubliés du développement économique./Territories and regions, the big 
forgotten of economic development», L'Harmattan Editions, Paris.

[21] Courlet C (1999), «Territoire et développement/Territory and development» in RERU, $n^{\circ} 3$.

[22] Courlet C \& Soulage B (1994) «Industrie, territoires et politiques publiques/Industry, territories and public policies» Paris, l'Harmattan Editions.

[23] Courlet C Pecqueur B (1996) «Districts industriels, systèmes productifs localisés et développement/Industrial districts, localized production systems and development» in Abdelamalki L, Courlet $\mathrm{C}$, « les nouvelles logiques de développement/Development new logics» coll. «Logiques économiques/Economic logics», Paris, Harmattan Editions, pp 91-102.

[24] Dimou M (1994) «La dynamique d'évolution des systèmes productifs locaux, une interprétation marshallienne du développement/The evolution dynamics of local production systems, a Marshallian interpretation of development $\mathrm{PhD}$ at UPMF, under the direction of Claude Courlet.

[25] Ferguène A (2002) «PME, Territoire et développement local: le cas des pays du Sud/ SMEs, Territory and local development: the case of Southern countries» a paper for the seminar «Deuxièmes rencontres des suds sur: Développement local et coopération décentralisée entre régions de la méditerranée/Second Meeting of Southern countries: Local development and decentralized cooperation between Mediterranean regions», Marrakech, October 10th $\& 11$ th.

[26] Ferguène A (2001), «Dialectique globale/locale et dynamisme endogène dans les pays en développement: exemples tunisiens./ Global/local dialectic and endogenous dynamism in developing countries: Tunisian examples » in "Perspectives" journal (URTSD), University of Badji Mokhtar in Annaba, $n^{\circ}$ 5, March.

[27] Garofoli G (1996) «Industrialisation diffuse et système productifs locaux : un modèle difficilement transférable aux pays en voie de développement/Diffuse industrialization and local production system: a model difficult to transfer to developing countries » in Abdelamalki L, Courlet C, «les nouvelles logiques de développement/The new logics of development» coll. «Logiques économiques/Economic logics», Paris, Harmattan, 1996.

[28] Garofoli G (1992) «Les systèmes de petites entreprises: un cas pragmatique de développement endogène/The systems of small enterprises: a pragmatic case of endogenous development » in Benko G, Lipietz A.

[29] Lebrorgne D, Lipietz A (1992) «Flexibilité offensive et flexibilité défensive, deux stratégies sociales dans la production des nouveaux espaces économiques/Offensive flexibility and defensive flexibility, two social strategies in the production of new economic spaces. » in Benko G, Lipietz A (1992), «Les régions qui gagnent, District et réseaux : les nouveaux paradigmes de la géographie économique/Regions that win, District and networks: the new paradigms of economic geography » PUF, Paris.

[30] Nadvi K, Schmitz H (2001) «Les clusters dans les pays en voie de développement : bilan d'expériences et perspectives de recherches/The clusters in developing countries: results of experiences and research perspectives. » in « Réseaux d'entreprise et Territoires, regards sur les systèmes productifs locaux/Enterprise Networks and Territories, a look at local production systems », Datar, La documentation française.

[31] Pecqueur B (2000) «Le développement local : pour une économie des territoires/Local development: for a territories' economy» Syros Editions ; Dijon.

[32] Pecqueur B (1996) «Dynamiques territoriales et mutations économiques/Territorial dynamics and economic changes» L'Harmattan, Paris.

[33] Pecqueur B (1992) «Territoire, territorialité et développement/Territory, territoriality and development » a paper for the international Seminar «Industrie et Territoire: les systèmes productifs localisés/Industry and territory: the localized production systems » Grenoble, October 21st \& 22nd, 1992.

[34] Pecqueur B (1987) «Tissu économique local et systèmes industriels résiliaires/Economic fabric and network industrial systems $»$ in RERU ${ }^{\circ} 3$.

[35] Perrat J (1997), «Une clé de lecture du rapport firmes/ territoires : la notion d'externalité/ A reading key of firms/territories relationship: the notion of externality », «Espaces et Sociétés», n 88/89.

[36] Perrin, J-C (1992) « Pour une révision de la science régionale. L'approche par les milieux/For a review of regional science. The approach by the milieu» in "Revue canadienne des sciences regionals", XV summer 1992, pp 155-197.

[37] Ragni L (1997) « Systèmes localisés de production: une analyse évolutionniste/Local production systems: an evolutionary analysis» in «Revue d'économie industrielle $», \mathrm{n}^{\circ} 81,3^{\text {rd }}$ quarter. 